\title{
Multilingual education in South Africa: the role of publishers
}

Article

Accepted Version

Edwards, V. and Ngwaru, J. M. (2011) Multilingual education in South Africa: the role of publishers. Journal of Multilingual and Multicultural Development, 32 (5). pp. 435-450. ISSN 17477557 doi: https://doi.org/10.1080/01434632.2011.592192 Available at https://centaur.reading.ac.uk/24759/

It is advisable to refer to the publisher's version if you intend to cite from the work. See Guidance on citing.

To link to this article DOI: http://dx.doi.org/10.1080/01434632.2011.592192

Publisher: Taylor \& Francis

All outputs in CentAUR are protected by Intellectual Property Rights law, including copyright law. Copyright and IPR is retained by the creators or other copyright holders. Terms and conditions for use of this material are defined in the End User Agreement.

\section{www.reading.ac.uk/centaur}

\section{CentAUR}

Central Archive at the University of Reading

Reading's research outputs online 


\title{
Multilingual education in South Africa: the role of publishers
}

Viv Edwards

National Centre for Language and Literacy, University of Reading, UK

Marriote Ngwaru

Institute for Educational Development, Aga Khan University, Dar es Salam, Tanzania

\author{
Correspondence details \\ Prof Viv Edwards \\ National Centre for Language and Literacy \\ The University of Reading \\ Bulmershe Court \\ Reading RG6 1HY \\ UK
}

Tel: 00441183788820

Fax: 00441183786801

Email: v.k.edwards@reading.ac.uk 


\title{
Multilingual education in South Africa: the role of publishers
}

\begin{abstract}
The South African constitution and related legislative tools provide a supportive framework for multilingual education. Successful implementation, however, requires appropriate learning materials and questions remain as to the vision and commitment of publishers to producing them. Based on an analysis of currently available books for children and interviews with publishers and key figures in the book value chain, this paper explores both the educational rationale for African language publishing and the issues that constrain expansion. These issues include the heavy dependence on the schools market in a society where the majority of the population cannot or do not buy books; the consequences of the slow implementation of the government language-in-education policy; and the particular challenges faced by small publishers. It argues that in order to move beyond dependence on the schools market, publishers need to look critically at the content of the materials they are producing, methods of reaching the huge, untapped markets and pricing strategies. It also considers differing opinions about the usefulness of translation in increasing the amount of reading material in African languages. Finally, it concludes that responsibility for finding a way out of the current impasse lies with both government and the publishing industry.
\end{abstract}

\section{Keywords}

South Africa, publishing, children's books, African language, education policy 


\title{
Multilingual education in South Africa: the role of publishers
}

\begin{abstract}
The South African constitution and related legislative tools provide a supportive framework for multilingual education. Successful implementation, however, requires appropriate learning materials and questions remain as to the vision and commitment of publishers to producing them. Based on an analysis of currently available books for children and interviews with publishers and key figures in the book value chain, this paper explores both the educational rationale for African language publishing and the issues that constrain expansion. These issues include the heavy dependence on the schools market in a society where the majority of the population cannot or do not buy books; the consequences of the slow implementation of the government language-in-education policy; and the particular challenges faced by small publishers. It argues that in order to move beyond dependence on the schools market, publishers need to look critically at the content of the materials they are producing, methods of reaching the huge, untapped markets and pricing strategies. It also considers differing opinions about the usefulness of translation in increasing the amount of reading material in African languages. Finally, it concludes that responsibility for finding a way out of the current impasse lies with both government and the publishing industry.
\end{abstract}

\section{Keywords}

African languages, education policy, children's books, publishing, South Africa 


\section{Multilingual education in South Africa: The role of publishers}

\section{Introduction}

The official policy of bilingualism in English and Afrikaans during the apartheid era in South Africa has been replaced by a policy of multilingualism embedded in the 1996 South African constitution, which recognizes a further nine African languages - isiNdebele, isiXhosa, isiZulu, Sepedi, Sesotho, Setswana, siSwati, Tshivenda and Xitsonga. In addition, various other policies and legislative tools, including the 1996 South Africa Schools Act, the Language in Education Policy (DoE, 1997) and the 2001 National Curriculum Statement, provide support for what in South Africa is usually described as mother-tongue-based bilingual education (Alexander 2003). At the international level, the arguments for this approach are well rehearsed: students who have a sound foundation in the mother tongue participate more actively, feel more confident about their learning and outperform peers who operate only through the medium of a second language (Baker, 2011). Successful implementation, however, requires the development of both appropriate pedagogies and learning materials. In this paper, we focus on the African language books for children which are essential for the delivery of effective multilingual education.

In spite of the apparently supportive policy environment, questions remain as to the vision and commitment of publishers regarding African languages. Beukes (2005: 14) for instance, refers to an editorial in the Sunday Times which describes publishing in indigenous languages as 'on its deathbed'. More recently, a Minister of Arts and Culture complained that he had 'abandoned the hope of the commercial publishing sector coming to the party' (Jordan, 2009). Many of the publishers we have spoken to, for their part, argue that reports of this demise have been exaggerated. Our aim, then, is to establish the extent of publishing in African languages and explore the issues which constrain expansion in this area. These issues include the dependence on the education market in a society where the majority of the 
population cannot or do not buy books; the consequences of the slow implementation of bilingual education; the particular challenges faced by small publishers; and differing opinions about the usefulness of translation in increasing the amount of reading material in African languages.

\section{Methodology}

We set out to address the first of our research questions - the extent of African language publishing for children in South Africa - using documentary evidence in the form of general industry surveys and the two main sources of information on African language publications: the 2007 Publishers' Association of South Africa (PASA) Writing in Nine Tongues catalogue and its 2008 and 2009 supplements; and the 2008 Department of Arts and Culture (DAC) Catalogue of South African Literature.

We addressed the second question - the issues that constrain the expansion of African language publishing - with the support of PASA, which helped us to identify and make contact with representatives of the entire sector: long established indigenous publishers and multinational corporations, as well as indigenous companies established in the postapartheid period. We undertook semi-structured interviews with a range of people in nine different publishing houses, including managing directors, commissioning editors, and marketing directors. Given the movement of personnel between publishers, many of those we spoke to had worked for several different companies. As such, their individual and collective experience of the issues was considerable. We were able to supplement the perspectives of publishers with those of a range of other stakeholders in publishing for children, including authors, translators, book retailers, book distributors, educationalists, NGOs involved in publishing and book promotion organizations, who we contacted through personal networks. 
Some twenty hours of interviews conducted either on a one-to-one basis or with small groups from the same organisation or company were transcribed and analyzed using HyperResearch, a cross platform qualitative data analysis software package.

\section{Extent of African language publishing}

African language publishing in South Africa is not, of course a new phenomenon. In the first half of the twentieth century, it was the province of missionary publishing houses. Although the introduction of Apartheid in 1948 severely curtailed the activities of missionaries, the separate provision established under Bantu education ensured a proliferation of African language titles, albeit characterised by what Mpe (1999) terms 'intellectual, critical and imaginative mediocrity'. While developments in the wake of the new 1996 Constitution are underpinned by very different political imperatives, it is unclear whether current production meets actual needs. The first issue to be examined, therefore, is the extent of African language publishing for children. Is it as limited as is sometimes suggested? Or are publishers justified in their claims that they are meeting current needs?

The PASA Annual Industry Surveys provide overviews of trends, including those affecting African language publishing. The 2008 Report, for instance, shows that just $9.5 \%$ of the sales of all locally produced books were in African languages, compared with $75.25 \%$ in English and $15.25 \%$ in Afrikaans (Galloway \& Struik, 2009). For a more nuanced view of what is happening in the sphere of publishing for children, however, we need to turn to the more detailed information on individual books contained in the PASA (2007) Writing in Nine Tongues catalogue and its 2008 and 2009 supplements and the DAC (2008) Catalogue of South African Literature. Writing in Nine Tongues includes well over 5000 different titles in isiNdebele, isiXhosa, isiZulu, Sesotho, Sepedi, Setswana, siSwati, Tshivenda and Xitsonga. The Catalogue of South African Literature includes almost 4000 titles, many of which overlap 
with Writing in Nine Tongues. However, its coverage is wider: listings are also in English, Afrikaans and the Khoi San languages spoken by earlier inhabitants of Southern Africa.

At first sight, these catalogues might suggest that African language publishing is flourishing. Closer scrutiny, however, offers a rather less optimistic picture. There is considerable overlap between the PASA $(2007,2008,2009)$ and DAC (2008) listings. Both sources conflate titles produced over a number of years, making it difficult to assess whether output in African languages is increasing, stable or decreasing. This judgment is particularly difficult in the case of Writing in Nine Tongues, which gives no information on the date of publication. There are also problems in knowing whether books remain in print. In addition, entries are divided among nine languages in the case of Writing in nine tongues and twelve languages in the case of the Catalogue of South African Literature. Further analysis points to serious gaps in provision for very young children and speakers of the smaller languages (Author, 2010).

\section{The schools market}

One of the defining characteristics of publishing for children across Africa is the very heavy dependence on the schools market (Wafawarowa, 2006). In South Africa, where the large majority of orders come from education departments, Section 20 schools with the authority to make purchases, libraries and NGOs involved in book distribution, 74 per cent of all locally published books are for the schools market (OECD, 2008: 178).

Figures 1 and 2 below underline the dominance of English in the education market. English books make up $73.2 \%$ of book sales to school despite the fact that English is spoken as a first language by only $8.2 \%$ of the population. This compares with $9.89 \%$ of sales of Afrikaans, spoken by $13.3 \%$ of the population and $16.62 \%$ of sales of the other African languages combined, speakers of which make up 78.5\% of South Africans (see Figure 1). 
Insert Figure 1 (Net turnover of local book sales to schools according to language) and Figure 2 (Title production for the education sub-market by language) about here

However, when we look at the number of titles produced for the schools market by publishers providing data on language, the picture becomes rather more complex (see Figure 2). African language books in 2008 made up the largest number of new titles (47.92\%), followed by English (39.77\%) and Afrikaans (12.31\%). The higher proportion of African language titles suggests awareness on the part of publishers of the economic importance of a market supported, in principle at least, by government policy. It may also reflect attempts to address the serious lag in production of books in African languages (see Kruger, 2009).

\section{Textbooks versus supplementary materials}

A further issue concerns the imbalance in the kinds of books available. One of the main differences between the schools market in the North - Western Europe, North America, Australia and New Zealand - and other parts of the world is the balance between textbooks and supplementary reading materials or 'real books'. In African classrooms, textbooks are the main - and in many cases - the only learning resources. At the foundation level, they usually take the form of workbooks and readers - series of books of increasing levels of difficulty written expressly for the purpose of teaching children to read. With older children, textbooks are either based around subject curricula - and are overwhelmingly in English - or, in the case of African language literature, take the form of set books.

In the North, developments in pedagogy have led to a far greater emphasis on 'real books' and reading for enjoyment. Traditionally, literacy was conceived as a set of discrete skills acquired through decontextualized exercises. More recently, the emphasis has been on more holistic approaches, where children learn to read and produce meaningful texts by behaving like real readers and writers (Edwards, 2009). There has been a corresponding shift from the artificial 
language of basal readers or reading schemes designed to teach key vocabulary or particular sounds to 'real books' - attractive, well produced stories that promote the idea that reading can be fun. In an African context, it follows that the stories should be written in local languages which allow children to use their knowledge of life and language to make meaning of, rather than simply decoding, the text.

Initiatives such as the Culture of Reading project (Bloch \& Alexander, 2003; Edwards, 2008) attest to the relevance of these developments in a South African context. 'Real books' are found increasingly in schools, assisted by national and provincial book promotion campaigns such as the 100 books in every classroom and Run home to read. Nonetheless English textbooks still predominate and their sales are used to cross-subsidize other kinds of publishing. From a publishing perspective, then, the main problem would appear to be the lack of spend on real books, more commonly known in Africa as supplementary materials, by the main client, the government. In South Africa, supplementary materials are difficult to find outside large cities and expensive. A further complication is that only a small proportion of schools, estimated in 2008 at 9000 out of more than 25000 schools OECD (2008: 186), have a library of any kind.

\section{Implementation of language-in-education policy}

One of the major obstacles to the expansion of African language publishing for the schools market is the slow implementation of language-in-education policy (Kamwangamalu 2000, Beukes, 2004; Heugh, 2007; Kruger, 2009). Despite the wide range of policies and legislation which provide support for multilingual education, African languages are currently used as 'languages of learning and teaching only in the Foundation Phase in schools serving predominantly “African” learners', where the transition to English often happens 'before learners have fully developed the necessary cognitive skills in their home languages' (DBE, 2009). 
In survey of parents undertaken by PanSALB (2000) the majority ( 88 per cent) expressed a preference for what would be, in effect, mother-tongue-based bilingual education. However, in the absence of such provision they inevitably veer to education in the language of highest status. The fact that the majority of learners continue to be taught through the medium of English as a second language is certainly a deterrent to publishing in African languages (DBE, 2009). Heugh (2007: 209) outlines two important consequences for education:

Publishers cannot and (will not) risk producing educational materials in African languages without guaranteed sales. Teachers cannot risk teaching more effectively through African languages because there is no material support for this... Parents from the more or less $75 \%$ majority recognize the current lack of educational materials in their language and try to move their children into the best resourced English medium state schools (approximately $6 \%$ of schools) or the $2 \%$ of privately funded schools.

The failure to firmly establish African languages as the main medium of instruction in even the first three years of school has far reaching implications for the publishing industry, summed up by one of the publishers we interviewed in the following terms:

Publishers want to know whether there is market out there for their books - that's how they make their money. Government hasn't said, 'We will buy those books for those schools'. So the ones that have published have taken a huge risk.

According to one source, 'There is not a publishing house in this country that is not sitting with warehouses full of books in African languages'. In the light of this experience and without the prospect of definite orders, risk-averse publishers are not prepared to commit.

Access to finance 
Publishers also face a range of other challenges in servicing the schools market. Some apply to all sectors of the industry; others relate to the size of the company, with smaller publishers experiencing disproportionate levels of disadvantage. In an age of globalization, this uneven playing field affects publishers in many different countries - the struggles of small independents relative to large multinational companies are well documented (Taxel, 2010). However, the history of publishing in South Africa raises additional challenges. The fact that those operating during the apartheid era were able to accumulate considerable wealth serves only to accentuate the differences between big and small players, requiring imaginative solutions if the desired redistribution of wealth is to be achieved.

Access to finance in order to ensure cash flow is an ongoing challenge for the smaller companies. The end of the apartheid era created potential opportunities for new entrants into publishing in South Africa. Many, however, have fallen along the way. Several publishers commented, for instance, on the length of time required for a return on investment:

From the time one gets capital to the time one gets the return can be as long as two years. That is why every time there is a new curriculum it wipes out a couple of publishers.

The upfront spend is quite high; you know, submitting the books and getting them approved is quite a long process. So often the books that we developed two three years ago are only now starting to get on the list. So you start with stock holding and all the development costs and often that's a barrier from entry into the industry.

A limited understanding of the book industry on the part of financial institutions exacerbates the problems faced by small independents. The seasonal nature of educational publishing, whereby most orders are received and processed in just four or five months of the year, is often not appreciated. As one small publisher commented: 
Even if you go to a financial institution and you look for funding, they say: "What do you do?' And you say: 'We make books'. And they say: 'Books?' We really struggled when we wanted to get funding... We are all struggling - struggling big time.

Access to finance is thus an on-going challenge with implications for marketing, distribution and compliance with complex procurement procedures.

Marketing requires large amounts of capital. Because of difficulties in accessing finance, low turnover companies established in the post apartheid era are only able to draw on small sales teams and cannot afford to produce large numbers of free samples. The main way of reaching schools is through visits from the sales team. Publishers able to place copies in the hands of those making choices are likely to do best. As the managing director of one high turnover company explained:

We printed and reprinted quite large quantities of our set works and we gave them away free to schools saying that, if they see our book, there is a very good chance that they will buy our book and that will lead to multiple copy sales. And it was an amazingly simple, expensive, but good strategy. We had an example of a book that was 15 years old and in its entire history had only sold approximately 300 copies. Then, after we did that, it sold something like 30,000 copies.

Small turnover companies, then, are faced with an uneven playing field.

Distribution also poses challenges. In provinces where all schools buy through a central requisition process, orders can be delivered in bulk to a small number of warehouses. Problems arise, however, in schools in rural areas responsible for buying their own books when small numbers of books have to be delivered across large areas. Large companies often have regional distribution centres or are able to take advantage of vertical integration, calling 
on specialist sister companies. Small publishers sometimes outsource distribution to specialist companies though, wherever possible, they deal with orders themselves: 'When we get a big order, if we can, we try and do it from the Joburg office because $10 \%$ for a big order is a lot of money to us'. Small publishers therefore tend to focus on the geographical area surrounding their main market.

Finally the complex book procurement process, while universally disliked, poses additional problems for cash strapped small publishers. Responsibility for book procurement is currently divided between provincial and national level. The process is further complicated by the fact that different provinces operate different systems. Calls for submissions are costly and come at different times, making it difficult to respond. There is, however, a good deal of support for shifting responsibility from the provinces to the national level, providing that this process is both robust and transparent. The coordination of the approvals process and the centralised placement of orders would make it possible to include languages other than English and Afrikaans in the same print run, thus reducing the unit cost of some of the less widely spoken languages. This approach would serve as a powerful incentive for publishers to produce books in a wider range of languages.

\section{The trade market}

The overdependence on the schools market is also highlighted by sales figures for 'trade' publishing that targets the general consumer through bookshops. Industry statistics have limited usefulness in discussions of publishing for children because they do not differentiate between books written for adults and children. Data on the breakdown of sales by language, however, point to the failure of African language publishing to penetrate the trade market (Kruger, 2009). English books make up $60.1 \%$ of the sales, compared with $34.45 \%$ for Afrikaans and a mere 5.02\% for other African languages combined (Galloway \& Struik, 2009). 
This situation is usually explained in terms of the absence of a culture of reading, a matter of widespread concern in South Africa, as witnessed by a proliferation of initiatives on the part of both government and NGOs to promote an enjoyment of books. In this section, we look critically at the arguments and suggest that, while the obstacles are very real, blue skies thinking about ways of expanding the trade market may offer a way out of the current impasse.

Developing a culture of reading

Most South Africans cannot or do not buy books (SABDC, 2007). The absence of a culture of reading is a very real issue for families with little disposable income and low levels of literacy. A question of particular concern is how to promote reading with pre-school children. While books purchased by Education Departments reach children of school age, younger children are largely dependent on the efforts of NGOs; opportunities to engage with books are very limited. And it is not simply a matter of putting books into children's hands: adults have an important role to play. As Carole Bloch, Director of the Early Literacy Unit at PRAESA (Project for the Study of Alternative Education in South Africa), an independent research and development unit attached to the University of Cape Town, points out: 'It's not the books initially, it's the contact with the significant adult who pulls them in. They could be singing or doing rhymes anything - but it happens to be from books. And then the books take over'.

The highly didactic, skills-based approach to reading which remains a widespread feature of South African classrooms does little to promote the notion of reading for fun. The emergence of reading clubs for children is an interesting development in this respect. The Vulindlela book clubs in Cape Town (organized by PRAESA and run by volunteers) regularly attract up to 100 children. The aim of the sessions from 10-12 on a Saturday morning is to create an atmosphere very different from school. The sessions start with circle games and singing. The children then divide into three different age-related groups to listen to stories and to stretch out 
or cuddle up with a book. The emphasis, then, is on reading as an enjoyable activity. English and isiXhosa are used in the Reading Club on alternate weeks.

While the promotion of a culture of reading remains a priority, it is important to avoid placing all responsibility on parents and children. Publishers also need to look critically at the content of the materials they are producing, their methods of reaching huge untapped markets and their pricing strategies.

\section{Content}

The publishers and booksellers we interviewed painted a consistent picture: most Africans do not engage with books and that those who do prefer reading in English. Discussion of why this might be the case tends to focus on issues such as the historical importance of oral culture, lack of disposable income and low levels of literacy, all of which clearly play a role. Assumptions about the reading behaviours of African adults, however, are often overly simplistic. As one of the publishers remarked: 'People often say black people don't read. A lot of rubbish! Of course they read, but for some reason they don't buy books'. The lack of reading culture would seem to relate - in part at least - to the failure of books to speak to the interests of potential readers.

There are many indications that Africans do read when the content is affordable, accessible and of interest. Vukani, the weekly bilingual English and isiXhosa newspaper, is distributed in the Cape Town townships; Isolezwe, the daily isiZulu newspaper in Durban, has a circulation of more than 95,000, outperforming the English-language dailies from the same publisher. Evaluations of a Soul City health promotion initiative show that high-quality glossy African language booklets distributed as inserts not only reached large numbers of the target audience receiving the newspapers but were also shared with others Goldstein et al., 2005). The 
enthusiastic public debate on radio about which books constitute 'classics' in the lead up to the launch of the Reprint of African Language Classics project at the Centre for the Book also suggests that there is indeed an interest in African language books, though the extent of their appeal is unclear.

An important issue, it would seem, is relevance. The content of books for younger readers is less problematic. The growing number of South African authors, such as Carole Bloch, Niki Daly, Phindi Dlamini and Gcina Mhlope, has ensured that children's books now speak to the everyday realities of a broad range of South African children. Much African language publishing for older readers, however, fails to meet this criterion. It is hard to disagree with the following assessment offered by one of the publishers we interviewed:

Most of the African languages publishing has been aimed at set work adaptations where the perception of the publishers is that they have to uncover serious themes, lots of characterisation, lots of meaty stuff to study. I ask myself do I read that sort of book? I read a lot but I don't ever read that sort of book outside my work environment because it would bore me to death. I don't go and read Dickens for pleasure, I don't read Shakespeare for pleasure either although I read them both when I studied at university. If you look at African language literature, you don't find things like Wilbur Smith where there's lots of action, easy reading and you can associate with the hero. Make it more light hearted, more action, more fun!

There is undoubtedly a need to explore which genres and themes speak to the interests of Africans. One promising example is the Nollybooks chic-lit romance fiction aimed at the young adult black market which is currently not catered for. Their publications are more accurately described as 'bookazines' - texts of around 30,000 words followed by suggestions for talking points, quizzes and a celebrity spot. Another gap in the market has been identified by BK publishing in the form of highly illustrated short stories aimed at recently independent 
readers making the transition to longer texts which require more stamina. In the case of both these publishers, the emphasis is on recreational reading in English, but there is no reason why this principle should not be extended to African language books.

\section{Distribution}

The normal way of reaching the trade market is through bookshops. The reluctance of the main retailers to stock African language books was a widespread complaint. Booksellers tend to attribute this reluctance to the lack of reading culture and the preference of Africans who $d o$ read for books in English: 'People think: I can appreciate a Zulu book but when it comes to buying I'm still going buy the English one'. Publishers, for their part, talked in similar terms about the difficulties they faced in persuading bookshops to stock and sell their African language books:

They will probably tell you that this is not worth shelving space. I mean people don't buy them because the person who goes to [shops in the $\mathrm{X}$ chain] is not your average person who is interested in African languages.

We obviously visit shops and we would try and coax them to keep our African language set works literature and books that we think are of general appeal. And very often they don't want to and then - when they do accept - with some of them the feedback we get is that they don't sell ... if you sell 20 you find 18 come back after a year. A very large number of our African population simply haven't got enough spare money to, and that's an obvious major thing.

The depressing circularity in discussions of retailers' reluctance to stock African language books invites blue skies thinking. We encountered two such examples.

The strategy of Nollybooks is that, since their target audience doesn't currently enter books shops, they need to take the book to the reader, making their titles available at magazine retail 
outlets and through direct sales agents. Working very much like Tupperware parties, agents are able to introduce readers to the brand and make commission on sales.

BK Publishing is also developing a range of highly innovative strategies, including door-todoor sales in townships and book promotion competitions in schools. Considerable emphasis is being placed on entrepreneurship and using books as tools for poverty alleviation and community upliftment. For instance, through a partnership with an NGO working in disadvantaged communities, they facilitated workshops which enabled over 50 youths to start their own bookselling ventures. During the workshop participant were each supplied with ten copies of a children's book as start-up stock and were required to develop a marketing strategy. All participants managed to sell all their copies within two weeks using personal networks, market stalls and other means. Additional strategies include book related competitions and book launches in township schools, as well as fund-raising events which help to subsidise books so that they can be sold for as little as R5.00.

\section{Pricing}

The final ingredient in bringing books to a much larger market is pricing. One very obvious reason why many South Africans don't buy books is that they have little or no disposable income. As Loreto Trok, publishing director for the NGO, Room to Read, commented:

Books are expensive, they cannot buy books, and they are poor... You think they are interested in buying a book when there is no mealie meal at home? No, they will not buy a book if there is no mealie meal at home or if there is no bread or the children don't have shoes or they can't even afford to pay school fees. 
Pricing, then, is a major issue. In this respect, it is interesting to note that newcomers on the publishing scene such as Nollybooks and BK publishing are making a concerted effort to lower prices, with Nollybooks retailing at R50 and the BK titles at R30, which compares with a retail price of around $\mathrm{R} 100$ for most books of comparable length.

A basic requirement for changing attitudes towards books and reading, then, is to ensure easy access to good quality, culturally appropriate books. The current book buying public of South Africa is estimated to be 50,000 out of a total population of 48 million people (SABDC, 2007). Increasing this constituency by even a modest proportion would be highly advantageous for the book value chain; it would also allow them to reduce the price of books to more realistic levels. This, in turn, would have an extremely beneficial effect in promoting a culture of reading, with obvious implications for levels of literacy and educational outcomes. Blue skies thinking of this kind thus offers a very promising way out of the current impasse.

\section{The role of translation}

Translation into African languages has emerged as an important issue for publishers (for further discussion, see Edwards \& Ngwaru, 2011). Some embrace translation as a means of increasing the number of books available for children with minimal effort; others express frustration around the translation process, which is sometimes perceived to be as costly as originating materials in African languages. Problems tend to centre on the varying stages of standardization of African languages. Typical publisher comments included:

What intrigues me is that we can get a Xhosa manuscript from the Eastern Cape and you can give it to a Xhosa academic at a university in Pretoria or Johannesburg and he will suggest many corrections. And those corrections will be made and will be returned to the Xhosa academic in the Eastern Cape and he will say that's all wrong. 
Publishers sometimes find themselves facing problems as to who to commission for particular projects in African languages... Sometimes someone would frown upon a book simply because the language the Setswana there is not their dialect - it's somebody's, but this is not our Setswana, it's their Setswana. And that in itself is a problem.

The development of terminology as part of a drive for the intellectualization of African languages (Alexander, 2005) is a closely related concern. The post-1994 government created the Pan South African Language Board (PANSALB) which, in turn, has established lexicography units for each of the official languages. In addition, a section directorate of the Department of Arts and Culture is charged with terminology coordination. For the moment at least, however, this official provision would not seem to be keeping pace with the needs of the publishing industry (Edwards \& Ngwaru, 2011).

In spite of such frustrations, decisions about which languages to translate appear to be driven mainly by potential sales. Most books are translated into larger languages like isiXhosa and isiZulu; smaller languages such as isiNdebele and TshiVenda are frequently overlooked (Edwards \& Ngwaru, 2011; Kruger, 2009). However, the educational rationale for making books available in the larger languages - laying a sound foundation in the mother tongue which will ultimately produce better educational outcomes - also applies to smaller languages. There are serious implications, then, for equality of opportunity between speakers of different languages.

Commercial imperatives also determine which genres are translated. In the 2009 supplement to Writing in Nine tongues, for instance, all the readers (normally sold as series and are therefore likely to generate larger numbers of sales) have been translated into African languages compared with very few titles that do not form part of a series. 
Not everyone shares the widespread concerns about translation. Neville Alexander, Director of PRAESA, considers the translation of books aimed at the education market into African languages as a 'process of trial and error' which will take many years to perfect and that the first steps towards quality translation are already in place (Edwards \& Ngwaru, 2011). In addition, a small minority of the publishers felt that the reluctance of their colleagues to translate across all official languages was simply an excuse for pursuing a more commercial course of action and chose to take a more strategic view. As part of their commitment of multilingual publishing, they prepare camera-ready versions in a range of languages ready to submit for approval and promotional purposes while minimizing risk by printing only when the orders come through.

\section{Moving forward}

The debate around African publishing in recent years has been heated, with criticisms aimed both at government and at the publishing industry. In order to move things forward, however, all parties need to accept responsibility.

For its part, government needs to understand the importance of minimizing the risks of publishers highly dependent on the education market. Official policies highly supportive of societal multilingualism remain largely at the level of rhetoric. The slow start in the implementation of mother-tongue based bilingual education in South Africa has had serious consequences for risk-averse publishers who have responded enthusiastically when sales are guaranteed, as in the case of core texts for older students, and readers for young children; but have otherwise focused mainly on the more commercially viable larger languages. 
This pattern of publishing, in turn, has implications for education. International research shows clearly that the best outcomes are associated with a strong foundation in children's mother tongues (Baker, 2011). The fact that publishers are producing fewer books for speakers of smaller languages therefore has repercussions for equality of opportunity for the children from these groups. By the same token, without the support of good quality materials, teachers will be reluctant to teach through African languages. The gradual introduction of bilingual education would help to achieve improved educational outcomes; it would also provide an invaluable boost for the publishing industry.

It is not reasonable, however, to place all responsibility for change on government. Publishers also have a role to play. South Africa has a world-class book industry that currently caters for about ten per cent of the population. The progress made to date in increasing the quantity and quality of books in African languages is encouraging. Far more work, however, remains to be done in identifying and producing materials of interest to the other 90 per cent. Such efforts need to focus not only on appropriate content but on ways of making books affordable and accessible to those readers who currently do not visit bookshops, and on of ways of reaching those that cannot afford them. Particular responsibility for innovation lies with the large publishing companies, many of whom accumulated considerable wealth in the apartheid era.

Political change in South Africa has created many opportunities for new entrants entrepreneurs, editors, writers in African languages, translators and booksellers - to the publishing industry. These opportunities are counterbalanced by huge challenges. In an age of globalization, some of these problems relate to size: small independent companies throughout the world find themselves competing on an uneven playing field where multinationals call the shots. The situation in South Africa, however, is particularly complex and cannot be reduced to a David versus Goliath struggle. 
One of the legacies of poor quality Bantu education is the need for capacity building across the sector. As Neville Alexander, Director of PRAESA, observed when interviewed:

You can't on the one hand say that apartheid was calculated to diminish peoples' minds, prevent them from having skills and then pretend that the day after apartheid has gone they're all competent. You've got to have mentorship and apprenticeship.

High turnover companies have been slow to recognize that the promotion of African languages is an effective way of implementing affirmative action within the framework of Black Economic Empowerment (BEE), the government programme launched to redress the inequalities of Apartheid by giving previously disadvantaged groups economic opportunities previously not available to them. Some are already involved in the mentoring of writers and illustrators, either on an informal basis or as part of empowerment deals. Others have the potential to contribute through the mentoring of smaller competitors in areas such as marketing. Workshops offered by the South African Book Development Council (SABDC) on various topics of interest to small and medium size enterprises provide a useful framework for moving forward. The importance of such mentoring and training cannot be underestimated. As one small publisher commented: 'Now we are beginning to see that there's so much out there that we haven't been able to tap on because - number one, we didn't know and number two, we didn't have the skills'.

It will also be important to develop other kinds of cooperation between longer-established companies and new entrants. India offers a possible model. A publisher specializing in books in Indian languages, describes an innovative partnership with multinational Penguin Books:

Together we do four books a year that are originated by Zubaan [an indigenous publishing house], edited by us, jointly produced, and then marketed and sold by Penguin and we have found a way of sharing the costs and the profits. For us, this 
arrangement represented an unusual step: it enables us to see whether our books could sell more or not; it enabled us to interact as equals with a much bigger, much richer, much more powerful partner because the arrangement had something in it for both of us; and it enabled us to get our authors known in a wider circle (Butalia, 2009)

There is a temptation for publishers to use the very real challenges around writing and translation as an excuse for limiting still further their exposure to risk-taking around African language publishing. This attitude overlooks the fact that both the standardization of English and Afrikaans and the development of children's literature in these languages have taken place over long periods of time. In short, it fails to understand that the emergence of children's literature in African languages is a work in progress. The director of a translation agency summed the situation thus:

The reality is that English has been around for eons and eons whereas African languages in their written form have only been around for the past hundred years. The market expects them to be at the same level. So I would like to challenge those people [that criticize] in asking them whether they've got the money to support the development of the genre.

While the problems are incontestable, they cannot be used as an excuse for refusing to move forward. Equally important, first steps in resolving these problems have already been taken.

\section{Conclusion}

The lack of disposable income and the absence of a culture of reading in South Africa have helped to make the publishing industry in South Africa very heavily dependent on the 
education market. The lack of political will to implement mother-tongue-based bilingual education has therefore had far reaching consequences. In the absence of genuine choice, parents gravitate towards English-medium education; risk averse publishers commit to African language publishing only where sales are more secure, as in the case of set books and readers, or supplementary readers for the large language groups; and teachers continue to teach through English in the absence of African-language materials.

While a small number of publishers show considerable commitment to publishing across a wide range of languages, the attitude of the majority might be described as that of benign neglect. There is, however, much scope for innovation. Some publishers are beginning to question the appropriateness of currently available African language reading materials and to look at more imaginative ways of delivering lower cost products. The recent attempts to showcase African language publishing in publications such as Writing in Nine tongues and the Catalogue of South African Literature demonstrate a growing awareness of the potential importance of this market. And the political leverage exerted by BEE offers a way forward for the empowerment of smaller competitors through mentorship, as well as other imaginative partnerships.

All parties, however, need to concede ground if African language publishing is to move forward. It seems appropriate therefore to end with Alexander's (2003) reminder of the promise offered by the new dispensation:

Although the gap between the constitutional and legislative position on the one hand, and the actual practices in the classrooms and lecture halls of the country on the other hand, remains very wide and often appears to be widening, the fact that these instruments exist is of the greatest significance. They represent democratic space for the legal and peaceful promotion of multilingualism and for mother tongue based bilingual education in South Africa. 
In the context of the present discussion, it is important to remember that the constitutional framework has the potential not only to improve the quality of education for the Africanlanguage-speaking majority in South Africa but also to stimulate the South African publishing industry, creating many new opportunities for speakers of African languages in the process.

\section{Acknowledgement}

The research reported in this paper formed part of the 'Interdisciplinary Perspectives on African Language materials for children', funded by the Leverhulme Trust.

\section{References}

Edwards, V. (2008) Culture of reading: an evaluation of a key programme of PRAESA. Cape Town: PRAESA.

Edwards, V. \& Ngwaru, JM (2010) African language publishing for children: where next? Retrieved from: www.ncll.org.uk/50_research/30_research_papers/AfricanLangPublishing.pdf

Edwards, V. \& Ngwaru, JM (2011) African language publishing for children: issues for translators. International Journal of Bilingual Education and Bilingualism. First published online 25 Match.

Alexander, N. (2003) Language education policy, national and sub-national identities in South Africa. Strasbourg: Council of Europe.

Alexander, N. (2005) The intellectualization of African languages. Cape Town: PRAESA/University of Cape Town.

Baker, C. (2011) Foundations of bilingualism and bilingual education. $5^{\text {th }}$ edition. Bristol: Multilingual Matters. 
Beukes, A. (2004) The first ten years of democracy: language policy in South Africa. 10th Linguapax Congress on Linguistic Diversity, Sustainability and Peace, 20-23 May, Barcelona.

Bloch, C. \& Alexander, N. (2003) 'Aluta continua: The relevance of the continua of biliteracy to South African multilingual schools'. In N. Hornberger (ed.) Continua of biliteracy: An Ecological Framework for Educational Policy, Research and Practice in Multilingual Settings. Clevedon: Multilingual Matters.

Butalia, U. (2009) Nationalism and Indian publishing. Retrieved from: www.indiaseminar.com/2009/600/600_urvashi_butalia.htm

DAC (Department of Arts and Culture)(2008) Catalogue of South African Children's Literature. Pretoria: DAC.

DBE (Department of Basic Education) (2009) Reply by Minister of Basic Education A Motshekga on questions posed in National Assembly for written reply, 9 October 2009. Retrieved from: http://www.info.gov.za/speeches/2009/09111016051005.htm

DoE (Department of Education) (1997) Language in Education Policy. Pretoria: DoE.

Edwards, V. (2009) Learning to be literate: multilingual perspectives. Bristol: Multilingual Matters.

Galloway, F. \& Struik, W. (2009) Annual publishing industry survey report 2008. Pretoria: Depertment of Publishing Studies, University of Pretoria.

Goldstein, S., Usdin'S., Scheepers'E. \& Japhet' G. (2005) Communicating HIV and AIDS, What Works? A Report on the Impact Evaluation of Soul City's Fourth Series. Journal of Health Communication 10(5): 465-483.

Heugh, K. (2007) 'Language and literacy issues in South Africa'. In N. Rassool (2007) Global Issues in languages, education and development: perspectives from postcolonial languages. Clevedon: Multilingual Matters, pp.187-217.

Jordan, P. (2009) Speech delivered at the launch of the Indigenous Literary Classics, National Library, Pretoria, 17 February. Retrieved from: www.nwpg.gov.za 
Kamwangamalu. N.M. 2001. The language planning situation in South Africa. Current Issues in Language Planning 2(4), 361-445.

Kruger, H. (2009) 'Language-in-education policy, publishing and the translation of children's books in South Africa'. Perspectives: Studies in Translatology 17(1): 33-61.

Mpe. M. (1999) Language policy and African language publishing in South Africa. Bellagio Publishing Network Newsletter 25, July. Retrieved from: www.bellagiopublishingnetwork.com/newsletter25/mpe.htm

OECD (Organisation for Economic Co-operation and Development) (2008) Reviews of national policies for education: South Africa. Paris: OECD.

PanSALB (2000) Language use and language interaction in South Africa: a national sociolinguistic survey. Pretoria: Pan South Africa Language Board.

PASA (Publishers Association of South Africa)(2007/2008/2009) Writing in Nine Tongues. Cape Town: PASA.

SABDC (South African Book Development Council) (2007) National Survey into the reading and book reading behaviour of adult South African. Retrieved from: www.sabookcouncil.co.za/research_development.html

Taxel, J. (2010) 'The economics of children's book publishing in the 21st century'. In S. Wolf, K. Coats, P. Enciso \& C. Jenkins (eds) Handbook of Research on Children's and Young Adult Literature. London: Routledge, pp. 479-94.

Wafawarowa, B. (1996) Intellectual Property Rights and Knowledge Production in Africa Retrieved from: www.iccwbo.org/uploadedFiles/ICC/policy/intellectual_property/pages/BrianWafawarowa.doc 


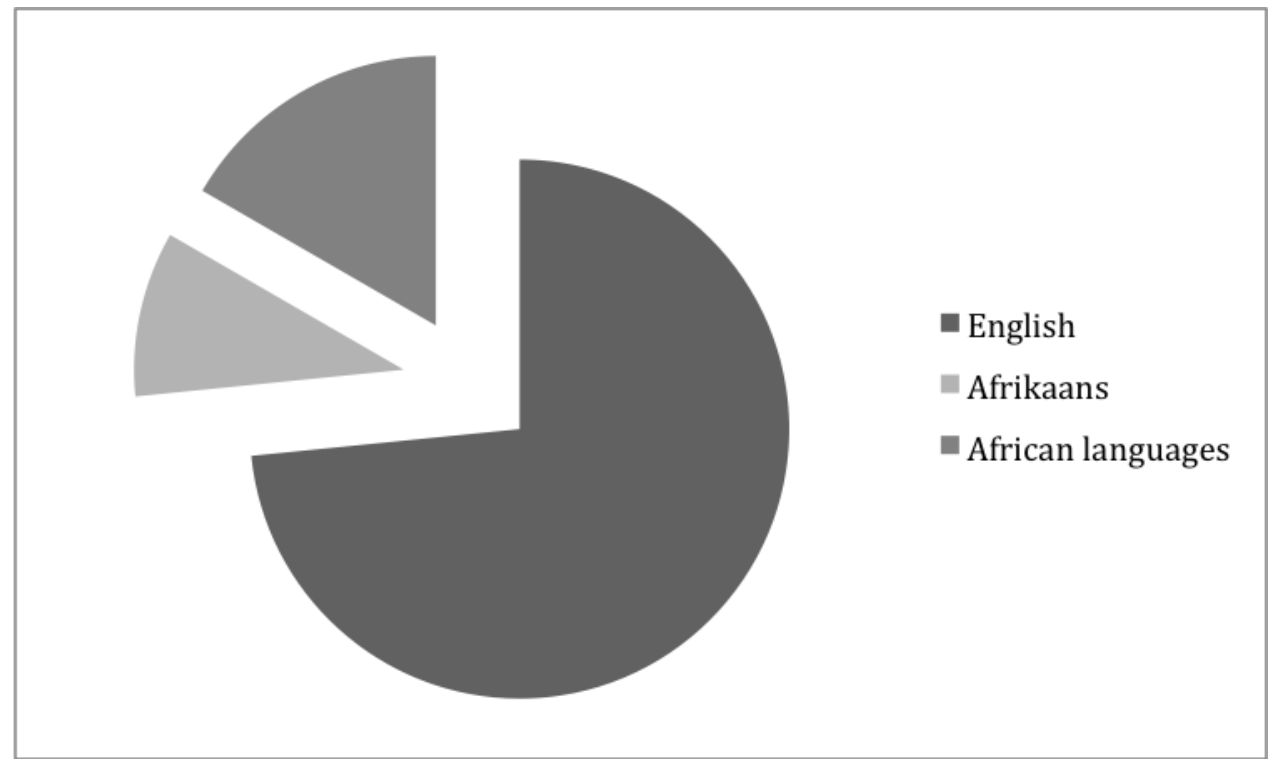

Figure 1: Net turnover of local book sales to schools according to language

[Source: Galloway \& Struik, 2009]

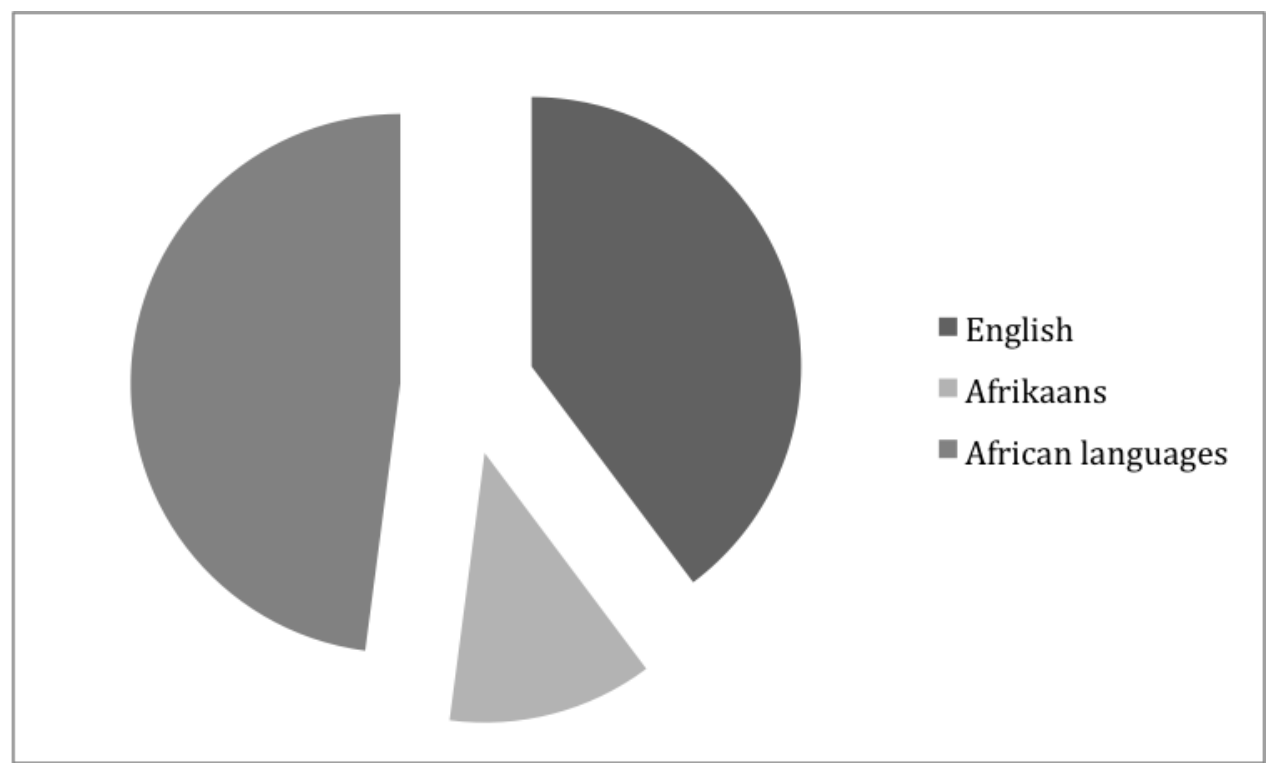

Figure 2: Title production for the education sub-market by language

[source: Galloway \& Struik 2009] 